\title{
The effectiveness of sustainable floating structures in the Gulf Region (Middle East)
}

\author{
A. Ghafooripour ${ }^{1}$, E. Nezamifar ${ }^{1}$, O. Ogwuda ${ }^{1} \&$ M. Sun ${ }^{2}$ \\ ${ }^{1}$ School of the Built Environment, Heriot-Watt University, Dubai, UAE \\ ${ }^{2}$ School of the Built Environment, Heriot-Watt University, Edinburgh, UK
}

\begin{abstract}
The use of marine environment for human life due to its positive effects on life style has created new ideas for offshore construction. In this new generation of offshore projects, the use of offshore pile-deck structures, sea reclamation by offshore soil embankment for creating the artificial Islands and floating structures (pontoon) in the Gulf region have been analyzed. The "World and Palm Jumeirah" projects in Dubai (UAE) and a project in the Kingdom of Bahrain are samples for marine reclamation. The "Mitra" project in "Kish" Island (Iran) is an example of a pile and deck system for offshore housing. The idea for a floating marina in Dubai is an example of a floating building (pontoon) in this region. This paper has studied these three different experiences for offshore construction using the weighted parameters ranking analysis method. Weight factors applied to the effective parameters based on clients/owners' and engineer's preferences. Results show that; although the reclamation solution is much more economic it cannot save the environment properly. A sustainable design of floating concept in the Gulf region for future extensions should gather all requirements economically and environmentally together.
\end{abstract}

Keywords: floating structure, pontoon, reclamation, pile-deck, offshore housing.

\section{Introduction}

The use of offshore structures for different purposes is one of the important prospects for engineering in history. Evolution of offshore constructions started from ancient era during Greco-Persian wars. The first Pontoon Bridges crossing Hellespont (today between Asian Turkey and European Turkey) were used professionally by Persians when Darius and Xerxes (Persian Emperors) 
expanded borders to Greece in Battle of Marathon (490 BC), and Thermopylae Battle (480 BC) [1,2].

In the Modern day offshore constructions has started from 1937 for developing the oil industry in the US.

Either growing global population and as a result limitation of lands or the need for better quality of life style yields attentions for the use of marine and offshore environment for other functions than industry and military purposes. Remarkable attempts have been made for the use of offshore constructions for residential communities, hotels, medical activities, and amusement parks worldwide $[3,9]$.

Today's situation shows lots of attention for the offshore construction in the Gulf region (Middle East) due to the harsh desert environment particularly in south side and more demands for a high quality of life style.

Recent studies and experiences show different offshore construction methods in the Gulf region. UAE (i.e. the pioneer for starting huge offshore projects), Iran and Kingdom of Bahrain have studied and conducted several projects for the use of marine environment. Different methodologies such as sea reclamation, piledeck structure and floating pontoons have been studied as offshore constructions in this region which would be considered as the pilot study/experience for the future projects (Figure 1).

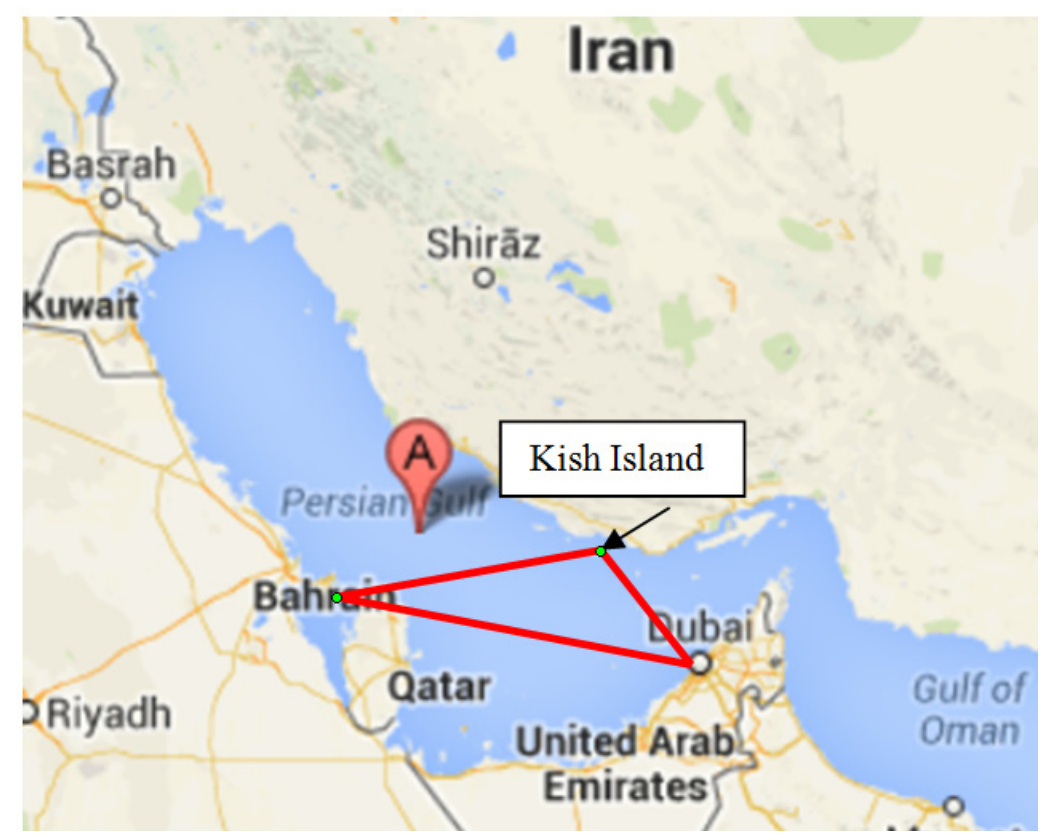

Figure 1: Locations of studied projects. 
The same approach for sea reclamation by National Assembly project has been started in the Kingdom of Bahrain. However, the use of jetties as the part of this job is also considered as a solution (Figure 2) [4].

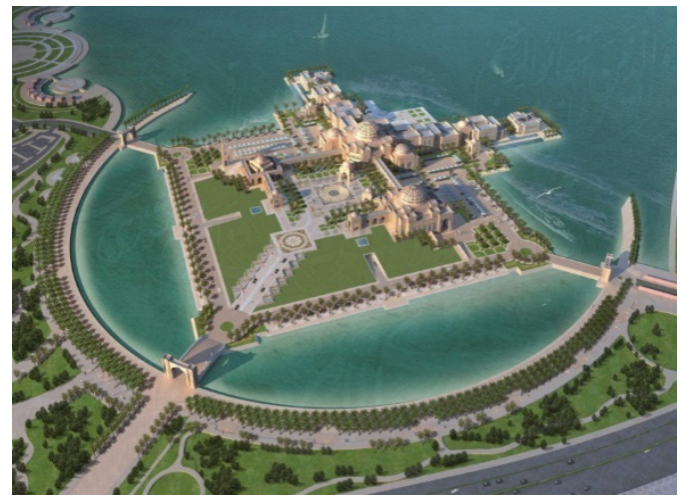

Figure 2: The National Assembly project, Kingdom of Bahrain.

The residential community started in Kish Island-Iran (Mitra Project) by using Pile-Deck technology (Figure 3) [5]. In most common practices, the use of breakwater for protecting coastal and offshore structures is a tradition and mainly costly. UAE and Bahrain started to have offshore projects behind the breakwater (e.g. crescent of Palm Jumeirah in Dubai) but, the Iranian project was studied
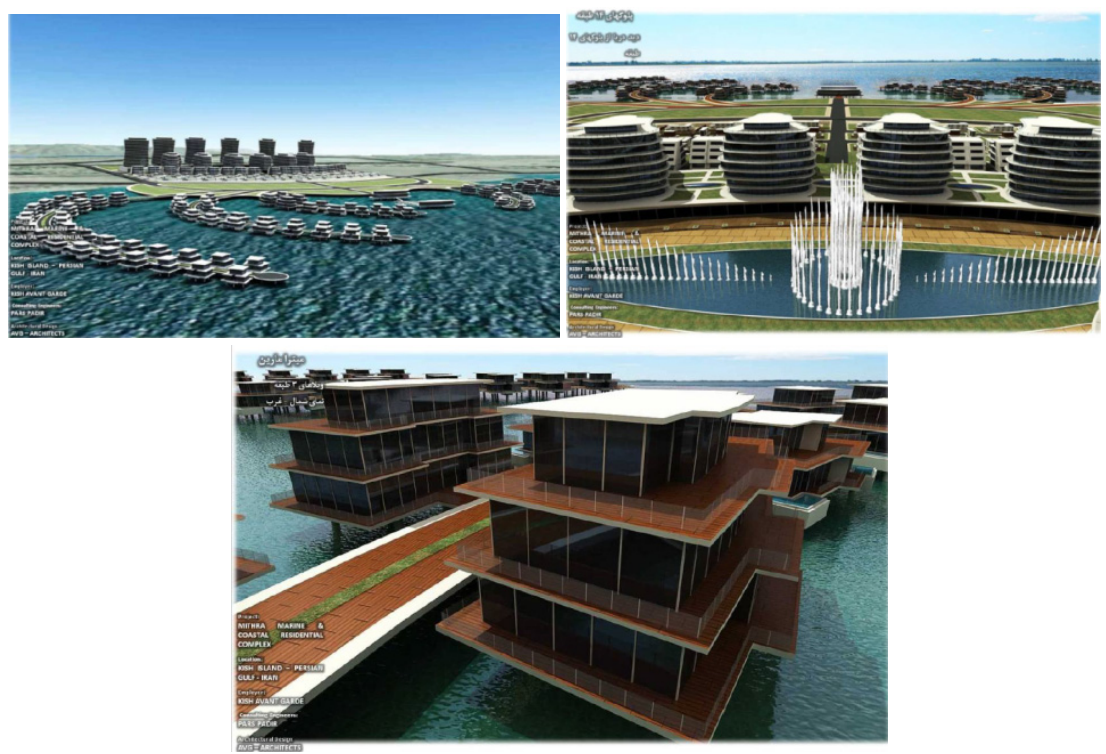

Figure 3: Mitra Project in Iran. 
and designed without having breakwater which is the advantage of using the Pile-Deck system.

UAE indeed, has the largest sea reclamation and offshore projects in the world such as Palm Jumeirah and the world Islands in Dubai. Some of them are the main destination for tourists in Dubai. Famous amusement Aqua Park and hotels are now working in those offshore reclamations (Figure 4).

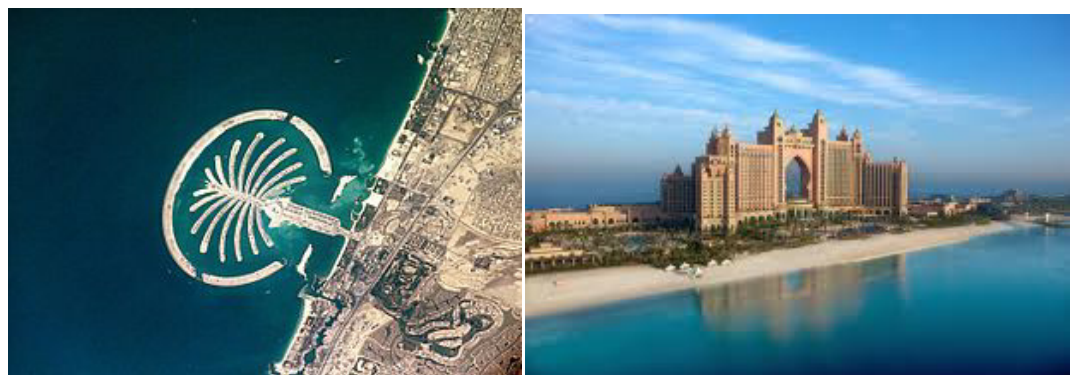

Figure 4: The Palm Jumeirah (left), offshore Atlantis Hotel in Palm (right) Dubai, UAE.

Floating offshore housing is another alternative for the Gulf region that has been experienced for small housing in the Royal Netherlands and marina in Dubai. Floating architecture means, a structure incorporating a floatation system, intended for use or employed for residential/public purposes, not usable in navigation and does not include a water craft designed. Therefore floating architecture can be defined as a building for living and/or working space on floatation system without navigation tool. In Dubai, marina constructions were designed and constructed on floating pontoons (Figure 5) [3, 6, 8, 9].
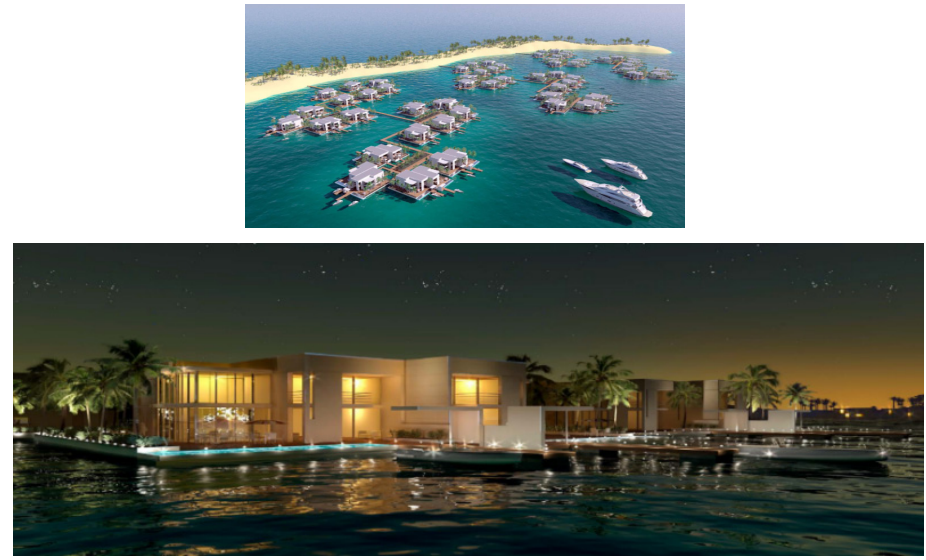

Figure 5: Floating residential communities. 
In the offshore construction technology, advanced design solutions, innovative ideas, and new concepts present a complex job. Decision making may need more studies and investigations to find a proper solution for every region.

This paper aims to compare these three different experiences/case studies for the Gulf region to propose some guidelines for the use of each system.

\section{Data collection for 3 case studies in the Middle East}

Three case studies in UAE, Iran and Bahrain have been investigated and compared. Although, Palm Jumeirah is one of the largest projects for reclamation, but this project includes some different floating marinas which is a good example for the use of pontoons as floating part for this case study and will show the existing experience in UAE (table 1).

Table 1: Technical information for three case studies.

\begin{tabular}{|c|c|}
\hline Project & Technical information \\
\hline $\begin{array}{l}\text { The National } \\
\text { Assembly [4] }\end{array}$ & $\begin{array}{l}\text { Location: Kingdom of Bahrain } \\
\text { Offshore area: } 103,406 \mathrm{~m}^{2} \\
\text { Project investment: } 48,000,000 \text { USD } \\
\text { Method of construction: backfilling sand until } \\
\text { desired design completed (reclamation) } \\
\text { Contractor: Vision Development Company } \\
\text { Soil mechanic: As per the } 12 \text { boreholes test the soil } \\
\text { is very soft, contains a lot of silt and sandy clay. }\end{array}$ \\
\hline $\begin{array}{l}\text { The MITRA } \\
\text { residential complex } \\
\text { [5] }\end{array}$ & $\begin{array}{l}\text { Location: Kish Island, Iran } \\
\text { Offshore area: } 27,000 \mathrm{~m}^{2} \\
\text { Project investment: } 68,000,000 \text { USD } \\
\text { Method of construction: Driven Piles with pre } \\
\text { stressed concrete deck } \\
\text { Consultant: Pars Padir Consulting Engineers } \\
\text { Soil mechanic: } 50 \% \text { silt, rest is coral }\end{array}$ \\
\hline $\begin{array}{l}\text { The Palm Jumeirah } \\
\text { - marina side with } \\
\text { pontoons [6] }\end{array}$ & $\begin{array}{l}\text { Location: Dubai, UAE } \\
\text { For the } 15,000 \mathrm{~m}^{2} \text { have been studied } \\
\text { Project investment: Circa } 25000000 \text { USD for } 1500 \text { - } \\
1700 \text { USD per square meter for all required } \\
\text { construction activities and materials. } \\
\text { Method of construction: Manufacturing the } \\
\text { pontoons, installation at site as well as stabilization if } \\
\text { needed. } \\
\text { Contractor: MARINETEK group } \\
\text { Soil mechanic: No information available and not } \\
\text { required for this type of construction. }\end{array}$ \\
\hline
\end{tabular}




\section{Construction process}

Different activities are required for each type of project which are summarized in table 2 .

Table 2: Construction process for three case studies $[4,5]$.

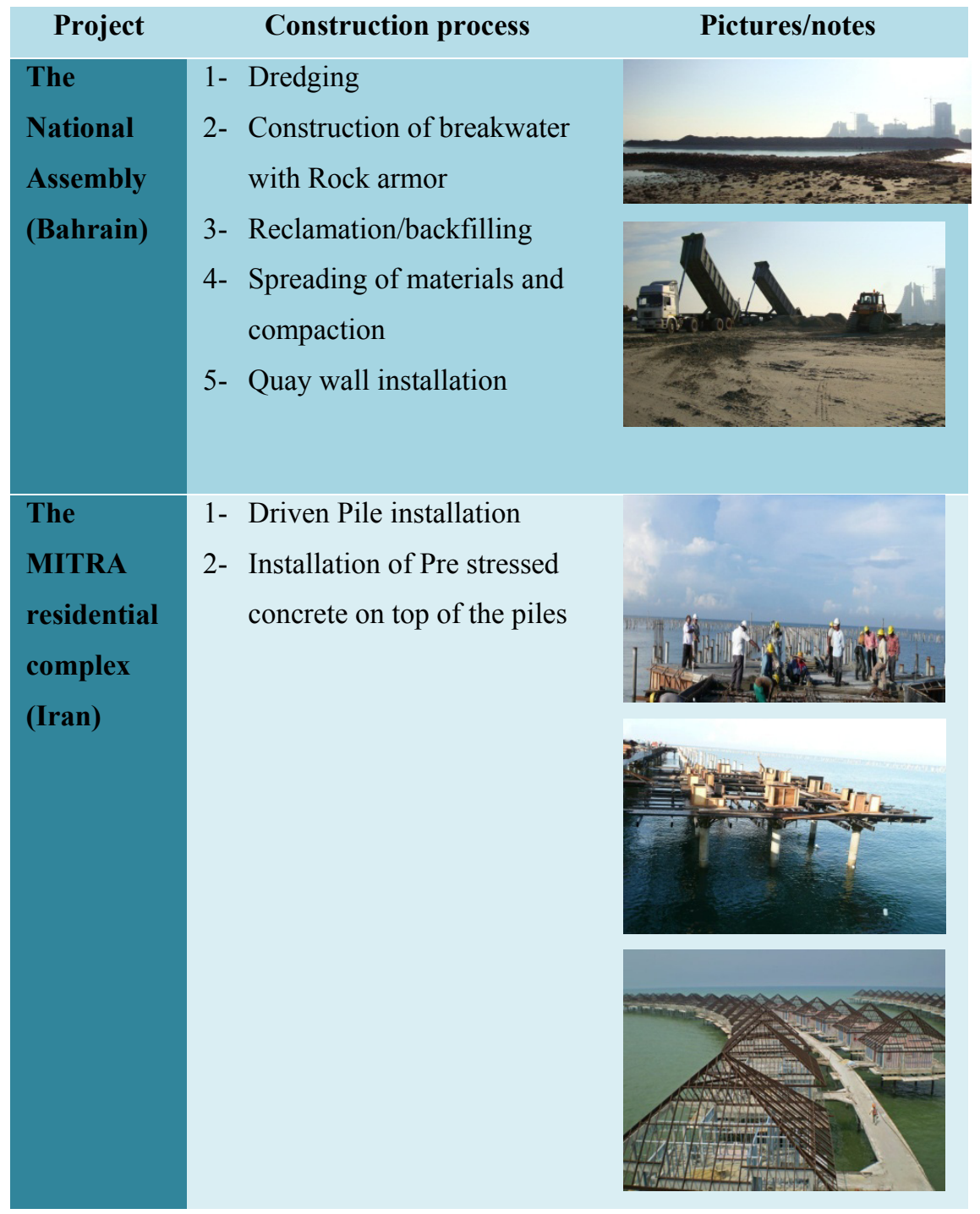


Table 2: Continued.

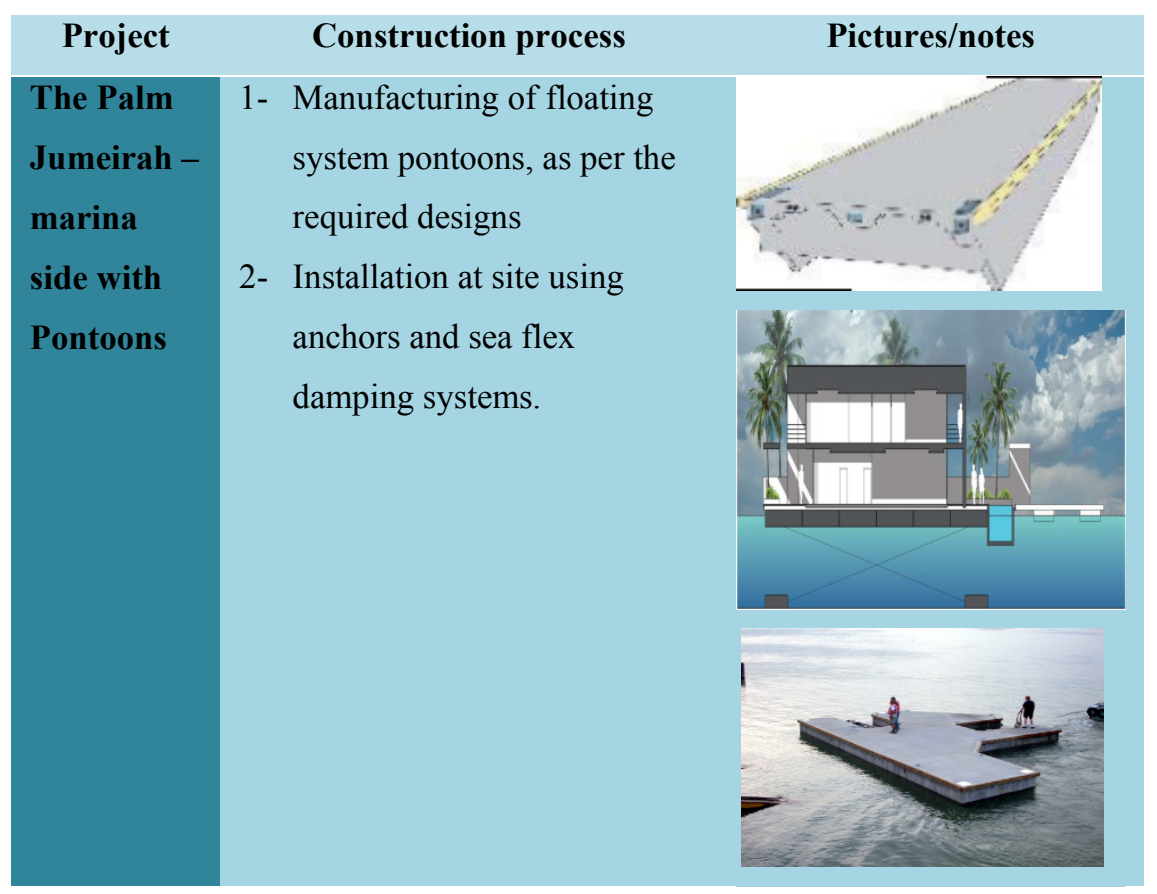

\section{Threats for each experience}

Each experience has its own threats which should be taken into account. Concerns can be summarized for the durability, stability/safety and maintenance expenditures. Also, design life would be another issue for investors to start an offshore project. For each experience these effective parameters have been summarized in table 3.

Design life for reclamation is normally considered more than 120 years and protection breakwaters are designed normally for 25 to 50 years, however, maintenance and some minor repairs will be required after this period.

Design life for floating and pile-deck system is normally considered between 25 to 50 years [7]. Therefore, a simple comparison shows that reclamation has more design life than floating and pile-deck solutions.

\section{Cost of projects}

Cost of projects have been estimated from the available bid data for both Bahrain and Iran cases (Figure 6). Data were collected from the pontoon's manufacturer for the unit area of the product and no official data were available for the project [4-6]. 
Table 3: Threats for each experience in the Gulf Region.

\begin{tabular}{|c|l|c|}
\hline Project & \multicolumn{1}{|c|}{ Concern } & \multicolumn{2}{c|}{ Picture } \\
\hline $\begin{array}{c}\text { National } \\
\text { Assembly }\end{array}$ & $\begin{array}{l}\text { Water pollution, } \\
\text { Environmental } \\
\text { impact on marine } \\
\text { life }\end{array}$ \\
\hline MITRA \\
Residential \\
Complex & $\begin{array}{l}\text { Corrosion of steel } \\
\text { piles, and structural } \\
\text { maintenance, no } \\
\text { serious effect of } \\
\text { environment }\end{array}$ \\
\hline Floating Projects & $\begin{array}{l}\text { This project has got } \\
\text { the minimum } \\
\text { impacts on } \\
\text { environment, risk of } \\
\text { sinking exists and } \\
\text { maintenance } \\
\text { required. }\end{array}$ \\
& \\
\hline
\end{tabular}

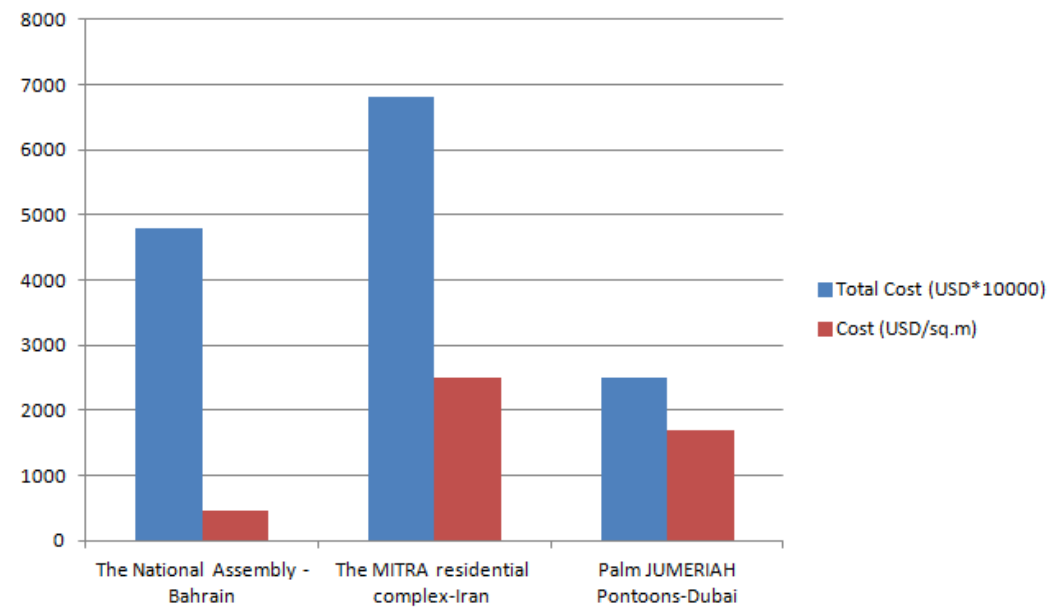

Figure 6: Total cost and price per square meter for three projects. 


\section{Data analysis}

For the aim of a reasonable comparison, ranking analysis using weighted effective parameters for each concept will be required.These data were collected by questionnaires and interviews from expert consulting engineers and some clients/owners for two different approaches to make a decision function for the project ranking.

A simple survey on these three experiences can easily show the ineffectiveness of cost trade-off analysis as a solution for decision making. All other effective parameters which were described shall be taken into account. In addition, today, the problem of saving the environment is becoming an important issue. Therefore, in some countries like Iran, development of marine structures is affected by environmental issues. Although the effect of environmental issues is not negligible, still, most of clients would like to learn about the minimum price.

Based on interviews in this investigation the weight factor of each parameter has been selected for two different approaches which can be observed widely in Gulf countries: Cost approach based on clients/owners point of view (Minimum Cost) and environmental approach based on local codes/designers' point of view (table 4).

Table 4: Weight factor for each parameter.

\begin{tabular}{|l|c|c|}
\hline Item & Cost wise approach & Environment wise approach \\
\hline Price & 0.5 & 0.3 \\
\hline Environmental impact & 0.2 & 0.5 \\
\hline Design life & 0.1 & 0.1 \\
\hline Maintenance costs & 0.2 & 0.1 \\
\hline
\end{tabular}

Weighted parameters in an optimization of a mathematical function (i.e. Decision function) can give a reasonable score for each case. Relative effectiveness values for each effective parameter in the decision function have been estimated based on the ratio of costs to engineering data which are available in this paper (Figure 7).

Therefore, decision making would be carried out upon the "Decision function" for each solution, which is coming from the sum of the effectiveness of each parameter for each concept multiplied by weight factors. This numerical series make a decision function and the sum of series will give the rank for each construction solution. 


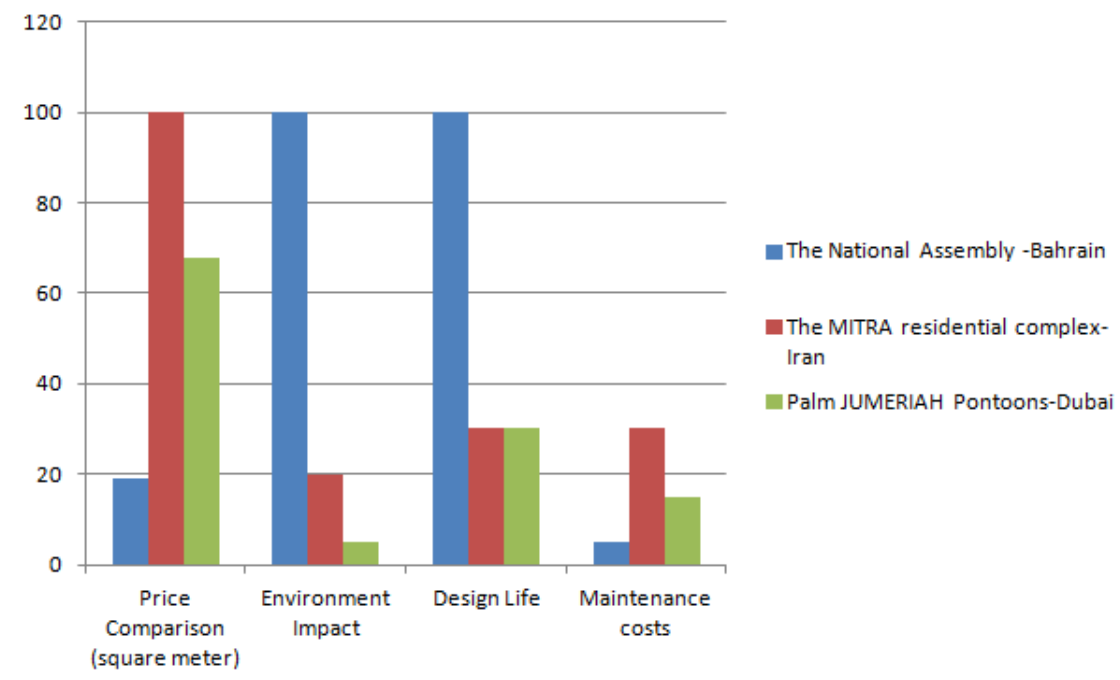

Figure 7: Relative values of effectiveness for each effective parameter.

\section{Findings and discussion on results}

With this ranking clearly the Bahrain project and similar projects in UAE (e.g. the world islands and Palm Jumeirah) have the best answer from financial point of view but their ranking for the environmental issue is lesser than the ranking of floating and pile-deck systems.

Clearly the pontoon and pile-deck systems are more expensive than the reclamation system but for the regions which they are very strict on environmental issues they would be the best answer.

Size of project will play a significant role in decision makings as well. A huge size project would be conducted by reclamation system, however floating and pile-deck solutions would be possible.

Pile-deck system has got lesser ranking for the price however this system will not need the breakwater so the effectiveness of pontoon and pile-deck for both approaches are likely close and both systems are classified as environmentally friendly (Figure 8).

\section{Conclusion}

This research shows a comparison between three different experiences in offshore construction in the Persian Gulf region. A numerical series of weighted parameters were used to make a rank for each solution. This research clearly 


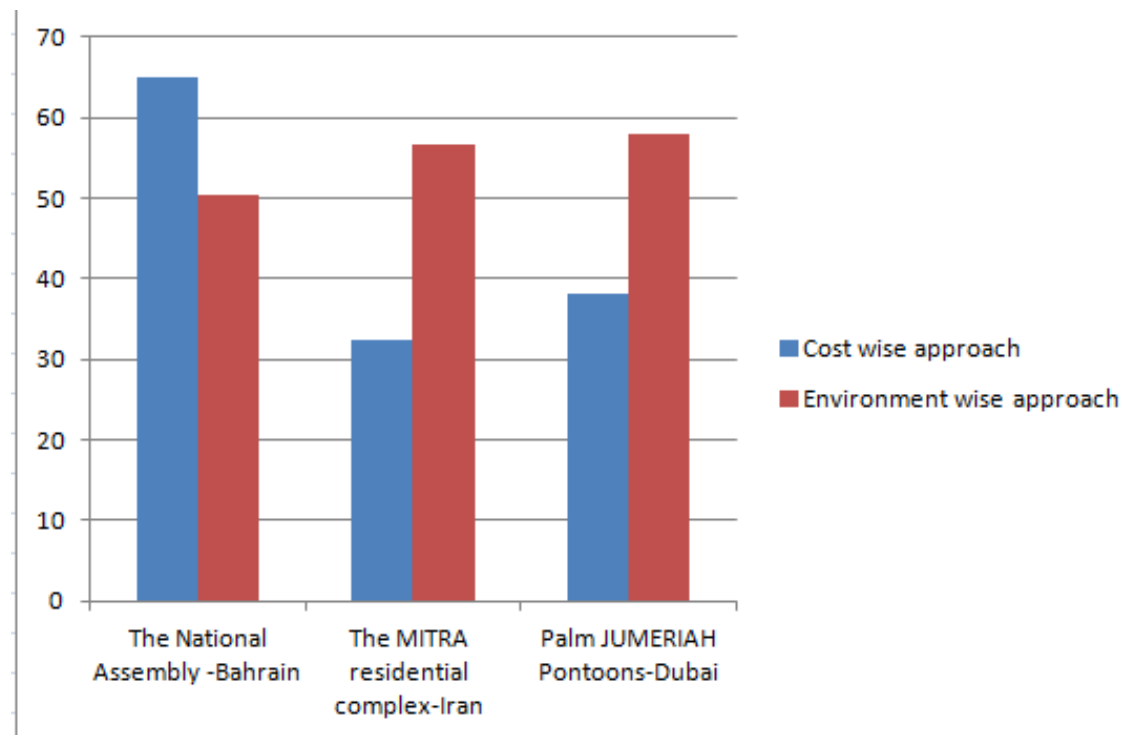

Figure 8: The sum of decision function for 2 different approaches.

shows that the use of floating systems in the Gulf area in Middle East would be a new feasible and reasonable solution for future offshore projects as an environmental friendly concept. Other important results are summarized as:

- Comparison between pile-deck/floating construction methods and reclamation shows that reclamation is an absolutely low cost method.

- Reclamation solution such as that experienced in Bahrain and in Dubai is useful for the large scale projects if the environmental issues do not have a serious impact on marine life.

- Pre-stressed deck with pile foundation is a very simple solution comparatively with the floating concept and it can be designed without breakwater. The price of it is much more expensive than the reclamation solution but it is categorized as environmentally friendly.

- Although a cost wise view makes the reclamation the best solution for offshore works, it cannot completely satisfy today's requirements for saving the environment and marine life.

- Floating solution as a new approach shows feasible and reasonable ranking for both cost wise and environmental wise point of views.

- The floating systems would be a solution for the future in the Gulf to develop sustainable projects. 
- It seems that sustainable design of a floating construction is much more practical compared with onshore constructions and makes it more economic. Further investigations will be required.

\section{References}

[1] Bailkey, Nels, (1992), "Readings in Ancient History", p. 175. D.C. Heath and Co., USA.

[2] Barkworth, (1993), "The Organization of Xerxes' Army", Iranica Antiqua Vol. 27, 149-167.

[3] Ziaee, Armaghan, (2013), "Dubai Sustainable Floating Hospital", Unpublished MSc Dissertation, I. Azad University, Dubai branch, UAE

[4] Yusuf Abdullah Zainal, (2011), "The national assembly project in Bahrain Engineering Documents", Vision Development group, Bahrain

[5] Ghafooripour Amin, (2012), "The MITRA residential complex project in Kish Island Engineering Documents", Pars Padir Consulting Engineers, Iran

[6] Milicevic, Alexander, (2011), "Floating Pontoons engineering documents", MARINETEK Group, Jebel Ali, Dubai, UAE.

[7] E. Watanabe, T. Utsunomiya, C.M. Wang, (2004), "Hydroelastic analysis of pontoon-type VLFS: a literature survey", Engineering Structures, No. 26, 245-256.

[8] Keuning, K. O.-D. (2010). "Float, Building on Water to Combat Urban Congestion and climate change", Frame Publisher, Amsterdam

[9] Mohammad, H.V., Ali, A.A., Abbas, A., (2009), "Hospital site selection using fuzzy, AHP and its derivatives", Journal of Environmental Management 90, 3048-3056. 